\title{
THE CONSTITUTIONALIZATION OF LABOUR RIGHTS: \\ WHAT BLISS IN THIS DAWN TO BE ALIVE
}

\author{
Canadian Association of Labour Lawyers \\ Saskatoon \\ 11 June 2010
}

\author{
Harry Arthurs \\ York University \\ Toronto, Canada
}

\begin{abstract}
Summary: In these remarks to an audience of union-side labour lawyers, I caution against excessive optimism concerning the potential of rights-based constitutional litigation to improve the lot of workers. Despite recent pro-labour Charter decisions of the Supreme Court of Canada, litigation will not fundamentally alter the underlying conditions which have disempowered workers and unions. This is not to say that the constitution is irrelevant, but rather that its most significant features are economic and political, rather than juridical.
\end{abstract}

\section{INTRODUCTION}

I'm here to talk to an audience of labour advocates who are out there doing god's work: defending the working class against the rampaging forces of hegemonic capitalism; pushing back against a couple of centuries of overt judicial hostility and a couple of decades of legislative indifference; trying to protect the rights, jobs and dignity of individuals who basically have no other recourse. So I'm here to talk to people whom I genuinely respect and admire. And I'm here at what might seem like one of the few hopeful moments that labour lawyers have experienced for many years - a moment when the Supreme Court finally seems to "get it", finally seems prepared to treat workers' rights as universal, fundamental and inalienable, finally seems willing to overturn legislation and rewrite the common law in order to vindicate those rights. Woodsworth said it best: "what bliss it is in this dawn to be alive!"

If I had any sense, any compassion, any modicum of good manners, I would just smile benignly, say "amen", present my expense account, and depart. And if this were indeed a blissful dawn, I would do just that. But it isn't, any more than Woodsworth's 
dawn was. His "dawn" was the French Revolution which - having produced the forerunner of our Charter - soon descended into terror and turned towards dictatorship. I'm not predicting that the revolution in labour rights launched by the Supreme Court is heading in quite the same direction. However, my message today a message you won't want to hear - is that at best our dawn is a false dawn and that at worst our revolution in labour rights may end up, like so many others, devouring its own.

\section{LABOUR RIGHTS AS FUNDAMENTAL RIGHTS}

Let me say up front that the notion that labour rights are fundamental rights, deserving of Charter protection, is on its face an attractive proposition. After all, workers are neither commodities nor factors of production; they are citizens. Surely if the Charter is used to protect citizens against oppression and to ensure their freedom and equality in the larger society it should also apply in the workplace, a site of serious oppression, little freedom and endemic inequality.

Moreover, from the labour's point of view, this new characterization of labour rights has some strategic attractions. The labour movement is in serious trouble. Workers no longer identify themselves as producers but as consumers; labour has therefore lost its raison d'etre as a class-based economic and political movement. Moreover, changes in labour markets and modes of production have also robbed the labour movement of much of its former economic power, while globalization has made its national focus increasingly anachronistic. As a consequence of these and other developments, workers in most advanced democracies confront greater individual insecurity and loss of collective agency than they have in decades. Arguably, embedding labour rights in the Charter enables the labour movement to rebuild its alliance with other rightsseeking groups. Engaging with constitutional rights discourse might conceivably renew its intellectual energy and refresh its message. And finally, if labour could secure solid protections for workers comparable to those that other citizens' movements have won under the Charter, if workers' rights - to organize, to bargain, to strike, to 
receive a living wage, to enjoy decent working conditions, to have a voice in workplace decisions, to be treated with respect - if all of these rights were reconceived as Charter rights, they too could be constitutionalized; and they too would be robustly protected. That at least is the hope.

\section{THE RIGHTS-BASED LITIGATION-DRIVEN JURIDICAL MODEL OF CONSTITUTIONALISM}

But what does it mean to "constitutionalize" labour rights? As l'll explain in a minute, there are several possible ways to think about "constitutionalization". However, for most Canadian labour lawyers, constitutionalization means first, that labour rights should be written into the constitution by amendment or judicial interpretation; second, that no statute or legal doctrine should be allowed to derogate from them; and third, that they should be justiciable, that workers denied their rights should be able to secure legal redress. The results of constitutionalization would be transformative - so many believe; the costs would be minimal; and the world would clearly be a better place.

This rights-based litigation-driven model of constitutionalization beguiles not only CALL members but friends of the labour movement, progressive thinkers and legal scholars who believe in the transformative potential of law. They all hope that litigating constitutional rights will somehow succeed in balancing capitalism's equation of unequal power, ensure social justice and put material flesh on the dry, legal bones of the liberal-democratic state. But now I have to admit, if you haven't already guessed: I am definitely not beguiled. I am an advocate of labour rights; a progressive; and (on a good day) a scholar: but I do not believe in the rights-based, litigation-driven model of constitutionalism.

That model of constitutionalism is found in its purest form in the United States, whose fundamental law guarantees freedom of association, assembly, expression and procedural due process. These guarantees might have been interpreted as protecting the right of workers to join unions, strike and picket, and be dismissed only on notice and for cause. But the courts held otherwise and labour's rights were not 
constitutionalized. Perhaps this explains why union membership in the private sector has fallen below $8 \%$, its lowest level in 100 years; why strikes are an endangered species; and why workers are presumed to be employed "at will" and subject to dismissal without notice or recourse. Or perhaps there are other explanations for labour's failures in the United States.

One way to evaluate the lessons of the American experience is to look at some international comparisons. A number of European countries have entrenched labour rights in their constitutions. And, sure enough, workers in those countries do seem to enjoy higher living standards, greater job security and more influence over their working lives than do American workers. But does this prove that constitutionalization produces better outcomes for workers? Or merely that countries where there is widespread political and social support for decent treatment of workers are more likely than others to constitutionalize arrangements designed to produce those outcomes? This much, however, is clear: in few, if any, European countries is U.S.-style rightsbased constitutional litigation used to effect fundamental changes in workers' protections or in labour market policies.

Canada provides another instructive comparison. Over the past decade or so, our appellate courts have held that under the Charter workers have the right to associate in unions, to call on their employers to bargain in good faith with that union, to picket and (perhaps) strike to advance their interests, and to be protected against legislative attempts to restrict those rights or to override collectively bargained agreements. The courts have also ruled that the industrial torts and the common law of wrongful dismissal must be reconfigured to accord with Charter principles. Is this not proofpositive that constitutionalization of workers' rights will revive labour's flagging fortunes?

Time will tell. But here is what time has told us so far: Our second labour trilogy Dummore, Advance Cutting and Pepsi Cola, all favouring unions - was decided in 2001 and 2002. From then until 2008 - the latest figures available - union density fell by $1.5-2.0 \%$. That's about the same rate of decline as it has experienced over 
the past thirty years. Let's update those figures. Over the past two or three years labour has won several more Charter victories - notably BC Health Services and Fraser. However, from everything we know, union density has not miraculously improved nor has union bargaining power taken a sudden spurt upwards. And let's look down the road twenty years: we can be pretty sure that union membership, power and influence will have declined not grown; that Canadian workers will enjoy the same wages or lower; that their jobs will be if anything more, not less, precarious; and that the social safety net that protects them against the vicissitudes of the labour market will have even more holes in it.

If the experience of the recent past and present means anything, and if my prediction of the future is right, it seems clear that the Charter has failed, and will continue to fail, to protect labour's rights and interests in the real world. This is hardly surprising. As I tried to demonstrate in an article I published a few years ago, all available evidence suggests that we have vastly over-estimated the Charter's potential to bring about social transformation. A moment's reflection on the American experience would have told us the same thing. Here's a country whose constitution has protected the fundamental rights of its citizens for the past 220 years; that has a hyper-developed rights jurisprudence; that has some of the world's most sophisticated constitutional lawyers, scholars and judges and a citizenry that is more rights-conscious than any other. But it's also a country whose citizens suffer from greater racial and economic inequality than anywhere else in the developed world; whose criminal justice system is more punitive and dysfunctional; whose democratic institutions are in gridlock; whose Supreme Court has just awarded ownership of its political process to corporations and lobbyists; and not coincidentally, a country whose working people and labour unions have been gradually but inexorably stripped of their rights and protections.

How can this be? Rights-based constitutional litigation ought in principle to be the best safeguard for workers' rights. Alas, in practice litigation is unlikely to alter the deep structures of society and economy that relegate workers to a subordinate role in their relations with employers. There are many reasons why this is so. 
Some of these have to do with the way constitutions are framed and interpreted:

- constitutions typically limit abuses perpetrated by state actors - not private or corporate actors;

- labour rights are necessarily couched in general language that can easily be read down;

- judges' understanding of labour issues is often outdated: how else to explain why the Supreme Court of Canada has embraced collective bargaining over the past decade, just when everyone else has given it up for dead?

Some have to do with the whole notion of a litigation strategy:

- litigation is expensive, slow and often inaccessible to individual workers or their representatives;

- evidentiary and procedural rules generally make adjudication unsuitable for the resolution of open-ended conflicts of social interests;

- remedies that might fundamentally transform labour's situation would require a redistribution of wealth and power that courts lack the capacity to design, a mandate to initiate or the means to implement;

And some explanations have to do with the paradoxical quality of labour's encounters with law:

- by pursuing their recourse within the existing constitutional framework, workers would be implicitly agreeing to abstain from using their economic and political power in ways that would radically alter that framework - a Faustian bargain they might well come to regret.

All of these considerations make me very doubtful that a rights-based litigation-driven strategy will end up achieving much for workers or unions. 


\section{ALTERNATIVE MODELS OF CONSTITUTIONALIZATION}

However, as I suggested earlier, the rights-based litigation-driven model of constitutionalization is not the only one available. Many states - in both the global North and the global South - have dealt with labour rights in their constitutions, often in language that is merely symbolic or evocative rather than tightly prescriptive. Some of these constitutions specify that legislation should be enacted to regulate employment relations, some that the state should strive to achieve just labour market outcomes, and some that employers and workers should collaborate in the management of enterprises. But oddly, while these states have "constitutionalized" labour rights they seem to end up adopting very different laws and policies, constructing very different labour market institutions and achieving very different degrees of industrial peace, social justice and national prosperity. In fact, there seems to be a total disjuncture between the constitutional model adopted to protect labour rights, on the one hand, and actual workplace and labour market outcomes on the other. I conclude therefore that outcomes are almost wholly attributable to nonconstitutional factors: to national demographies and endowments, to national histories and cultures, and above all, to the forces of national and international political economy. Nor is this counter-intuitive to anyone except lawyers.

Now let me return to the Canadian case. The Charter is not the only aspect of our constitution that shapes labour law. Federalism does as well. In assigning jurisdiction over labour matters to the provinces rather than to the federal government, the courts relied on constitutional language that gave the provinces the right to legislate concerning "matters of a merely local and private nature" and those involving "civil [that is, contractual] rights". This characterization of labour matters had important practical effects: it forestalled the emergence of national labour standards and labour market institutions; it prevented the federal government from implementing international labour standards without provincial consent; it helped to dissolve the national labour movement into often weak and sometimes warring provincial movements; it hampered attempts to launch a national social democratic party; and it invited regulatory 
competition amongst the provinces, an invitation the Harris government in Ontario (amongst others) accepted with alacrity. But most importantly, it constitutionalized contractualism as the fundamental principle of labour law. In other words, federalism rests on what I might call our political constitution - an array of beliefs about the nature of our society and how it ought to be reflected in the organization of the state. Here's what I mean: the old Snider view was that labour issues were matters for the parties to resolve contractually; the new $B C$ Health Services view is that they are unusually sensitive matters engaging important public policies and warranting legislative attention that meets the highest democratic standards. The old Labour Conventions view was that they are matters that have no inherent national or international dimension; the new $B C$ Health Services view is that Canadian workers are entitled to the same protections that the international community requires states to extend to all their citizens. This is not simply a change in thinking about the distribution of powers in our federation; it is something much more important: a fundamental revision of the political rationale underlying labour market regulation.

Indeed, I will go farther. The Charter itself, by protecting mobility rights, seems to acknowledge and reinforce the existence of a national labour market. It seems axiomatic, to me at least, that if there's a national labour market, there should be national labour market regulation. This is the principle that underlies CPP and El and federal-provincial cost-sharing arrangements for social services and health care; a principle that persuaded the provinces to cobble together a Canada-wide regime of pension regulation; and a principle that will become more explicit, pronounced and legitimate if the Supreme Court endorses the proposed national securities regulator. If I'm right, if there is indeed a shift in the locus of labour market regulation, it will highly consequential for labour law and for the power of the labour movement. Such a shift to recapitulate - would result from a fundamental revision of the way we characterize "labour". It would then have to be understood a cause, not a result, of the Supreme Court's change of heart over the past decade.

However, things aren't quite that simple. Like the rest of our economy, Canadian 
labour markets and labour market regulation are in the process of becoming not merely national but continental. Given the powerful influence in Canada of American public policies, political culture, legal concepts, financial capital and business ideology, a new preamble has been surreptitiously written into the Constitution Act 1867. Canada now has an economic constitution similar in principle to that of the United States. This recital does not necessarily imply slavish imitation, nor does it necessarily have juridical consequences, any more than did the old recital about having a political constitution similar in principle to that of the United Kingdom. But make no mistake: under American tutelage, we have accepted neo-liberalism as the default policy of our political economy.

This means that we will normally adhere to monetarist policies that enable governments to cool out labour markets by raising interest rates; that we will normally be taxationaverse, thus making the welfare state unaffordable; that we will normally regulate labour markets as lightly as possible and dis-empower the agencies and tribunals we once trusted to protect workers' rights; and that we will normally privilege business interests over those of other stakeholders. It also means that American and Canadian workers are now, more than ever, in competition for jobs both with each other and with workers offshore; that the trend to declining wages and benefits will prevail on both sides of the border; that strategies designed to ensure "union-free" workplaces will be peddled freely and pursued enthusiastically by both American and Canadian employers; and that HR policies designed to achieve flexibilization of the workforce will remain the universal response to global competition.

I have discussed rights-based constitutionalism and what I have described as political and economic constitutionalism. Next, I want to say a word about a different kind of constitution that I will describe as the "constitution of the enterprise". A good deal of research and debate in recent years has focussed on how workers are integrated (or not integrated) into the governance of the enterprise. Here l'll make special reference to North American experience which admittedly lags far behind the experience of many European countries whose actual experience, in turn, lags far behind the ideal-type of 
worker participation that is supposed to prevail in those countries.

In North America, we have undertaken four experiments in enterprise governance, each of which was ostensibly designed to protect workers' interests:

- the collective bargaining model which attempted to endow "citizens at work" with formal rights of association, voice and due process analogous to those they enjoy in the broader society;

- the "stakeholder" model which mandated management decision-makers to address the best interests not only of shareholders but also of workers, customers, suppliers and other stakeholders forseeably affected by corporate action;

- the "human capital" model whose rationale of enlightened self-interest was meant to persuade employers to treat workers as valuable assets worthy of investment in the form of good working conditions, benefits, amenities, training and, especially, trust; and

- the "worker capitalist" model which reminded workers that their pension and other benefit funds made them significant members of the shareholding class, with a stake in the success of predatory capitalism.

As things turned out, all four of these North American experiments in "constitutionalizing" labour's role in workplace governance failed. They did so in part because they sought to reform workplace governance without taking into account the aggressive form of liberal market capitalism that prevails in North America, and in part because they neither acknowledged nor addressed the internal political economy of the enterprise itself. The constitution of the enterprise, it turns out, cannot be reformed in isolation from the juridical, political and economic constitutions of the state. Or in another formulation: varieties of capitalism give rise to varieties of workplace constitutions, not vice versa. 


\section{CONSTITUTIONALIZING THE GLOBAL WORKPLACE}

Capitalism, as we all know, operates not only within but across national borders. Deep, institutionalized regional economic integration has been achieved in Europe; North America has gone some distance down that path; and regional trade regimes have begun to emerge in Latin America, Asia and Africa. The question is: will it be possible to entrench labour rights in whatever passes for the constitutions of these regional regimes?

Based on the European experience, one should not be too optimistic. Even the EU, which leads the world in this respect, has been oddly diffident about entrenching collective labour rights in its "constitution", though the Lisbon Charter seems to have moved the goalposts somewhat. NAFTA has been even more diffident, though the NAALC does begin to construct a rickety institutional structure for the protection of labour rights. But so far as I know, none of the other regional trade regimes has come close to entrenching labour rights, except perhaps in a symbolic sense. What about the WTO with its global mandate? That organization has a well developed dispute resolution process, and could in principle require that its members comply with labour rights a condition of participation in in the world economy. But it has resolutely refused to adopt such a requirement.

That leaves the International Labour Organization as the leading candidate for the protection of labour standards in the global economy. The ILO has promulgated almost 200 conventions defining the rights of workers; states that ratify these conventions are obliged, under the ILO charter, to implement them. Moreover, the ILO has identified a core of labour rights whose implementation is required of all member states even without ratification, simply by virtue of their membership in that organization. And finally, ILO conventions have clearly influenced national laws and constitutions by osmosis as well as by explicit adoption. But does all of this confer constitutional status on the ILO's 200 conventions or make them the fundamental norms of governance in workplaces across the global economy? By no means. 
Clearly, the entrenchment of fundamental labour rights in global workplaces presents great challenges. The very nature of global corporations makes them relatively impervious to transnational regulation. Global workplaces often form part of a transnational value chain linking corporations with widely-dispersed partner firms, subsidiaries and arm's-length suppliers. It is therefore often difficult for workers to identify their ultimate employer. Second, given that their operations can be moved relatively freely to different sites along the value chain, or off-loaded entirely, global employers are easily able to escape both legal constraints imposed by national governments and pressures generated by transnational unions or social movements. Third, even if ILO norms were somehow "constitutionalized", somehow embedded in national constitutions, would workers be able to take advantage of them? Their ability to do so is radically constrained because they are located in different countries, speak different languages, are regulated by different national laws, have different (or no) traditions of concerted action, experience different material circumstances and social environments and may not even realize that they share a common employer.

These are all formidable practical barriers to constitutionalizing employment relations in global enterprises. And let me add one more: the workers most in need of protection are often located in the countries of the global south, where labour standards are likely to be lower than in the global north. However, attempts to project labour standards from north to south are almost certain to be regarded as a threat to the comparative advantage of developing countries and as the manifestation of neocolonialism.

So: the constitutionalization of labour rights in the global context is almost unthinkable for practical and political reasons. And for conceptual and institutional reasons as well. There is, as yet, no global constitution, legislature, executive or judiciary, no global labour legislation, no global labour inspectorate or global labour movement. These are all obvious impediments to the constitutionalization of labour rights on a global scale. However, to be fair, some evidence suggests that labour rights are taking 
hold in places where they never existed before. Under attack from unions, social movements and political opponents, governments of the home countries of global corporations sometimes try to persuade or pressure those corporations to behave decently when they operate abroad. To some extent as well, acceptable labour standards become embedded in corporate policies, practices and routines of work that are disseminated outward from the head office to all the elements of the global enterprise. And finally, to some extent, ideas about labour rights - like ideas about sport, style and sex - seem just to percolate across borders, at both the grassroots and the elite level; through the media and by word of mouth; and with both positive and negative consequences.

I mention these promising developments in order to suggest that sometimes constitutions are created from the bottom up rather than the top down, that they may result from an accidental concatenation of unrelated events rather that from the deliberations of august assemblies, that they may be shaped by practical struggles in particular domains rather than by the comprehensive designs of legal architects. That certainly was the historic trajectory of the British constitution; and perhaps it will be the trajectory of global constitutionalism as well.

\section{CONCLUSION}

I have framed this last observation as a commentary on the constitutionalization of labour rights in the global economy. But now, in conclusion, I will suggest that it applies as well to domestic constitutions. Clearly states can adopt juridical constitutions; they can entrench labour rights; they can make those rights justiciable; they can authorize citizens to sue to defend their rights; and they can authorize the courts to award them remedies. In fact, this sort of constitutionalization proceeds at a manic pace: since 1789 national constitutions have had a median life span of 17 years, and an average life span of less than half that. But what does this sort of constitutionalization signify? Do we really imagine that each new constitution brings fundamental change to the state that adopts it? that rights made justiciable thereby 
become effective in the real world? that citizens and workers endowed with those rights will actually be empowered? that courts that acquire remedial powers can and will attempt to use them to realign the deep structures of economy and polity? and that if they do so, they will succeed in transforming global capitalism and making the world better for workers?

I have asked a series of questions that are, in fact, variations on a single theme: scepticism about rights-based, litigation-driven juridical models of constitutionalism. But even though I'm a law professor, I know that I can't end these remarks with questions nor will scepticism earn me a graceful exit in this gathering of practical lawyers. I therefore conclude by offering four hypotheses about the future of labour law that are, in my view, entirely plausible:

- the constitution that counts is the "real" constitution that expresses, normalizes, legitimates and therefore reinforces actual-existing relations of power: this is the political and economic constitution, not the juridical constitution what entrenches rights and grounds litigation;

- in the event of conflict, this "real" political and economic constitution will prevail over juridical constitutions;

- strategies designed to produce significant change though constitutional litigation will therefore prove in the long run to be disappointing for labour; but

- (my final hypothesis) workers make constitutions, not the other way 'round; the history of labour law clearly demonstrates that workers with an inclination and capacity for collective action will find a way to vindicate their "rights" and protect their interests, whatever the constitution might say, however the courts might rule and whatever lawyers and law professors might tell them. 